\title{
BENEFITS OF BIOCHEMICAL PARAMETERS OF SYNOVIAL FLUID AFTER DEATH
}

\author{
Reham A. Amar, Mohammed A. Hashem, Eman I. Hasan\& Sheeren A. AbdElaleem \\ Forensic department of medicolegal authority \& forensic medicine and clinical toxicology \\ department, faculty of medicine, Minia University
}

\begin{abstract}
Determination of time of death from postmortem changes such as cooling and rigor mortis will be less accurate by progression of postmortem interval (PMI). So, there is another method for estimation of time of death which can withstand putrefactive changes, such as biochemical analysis of body fluids. Aim: this study was done for estimation of time passed since death by analysis of synovial fluid parameters urea, creatinine, sodium $(\mathrm{Na})$, potassium $(\mathrm{K})$, calcium $(\mathrm{Ca})$, chloride $(\mathrm{Cl})$, and glucose. Methodology: Twenty-six cadavers were examined at postmortem interval: 6-12h, 1318h, and 19-24h. Results: The results of biochemical analysis in different PMI revealed that urea and $\mathrm{Na}$ levels had insignificant change. Each creatinine, $\mathrm{Cl}$, and $\mathrm{Ca}$ showed significant change and weak correlation with time lapsed, but the correlation with glucose was moderate. Conclusion: measurement of glucose + chloride followed by glucose alone in synovial fluid may be helpful in determination of PMI.
\end{abstract}

Keywords: PMI, synovial fluid, electrolytes, kidney function and glucose

\section{INTRODUCTION}

Determination of time passed after death is very important medico-legally in each post-mortem examination. PMI is the length of time from death till corpse discovery (Singh et al., 2006). Many studies pertaining to electrolytes, glucose, glycated hemoglobin, and hormones in several biological fluids have been studied and so support the role of biochemistry as a good tool in forensic pathology (Palmiere et al., 2012)

Synovial fluid biochemical analysis could be helpful in estimating postmortem interval as it can withstand putrefaction and more protected and less prone to burns or atmospheric variations (Sheikh, 2007).

Extensive characters about synovial fluid have been known for at least four decades. Measurement of synovial fluid electrolytes and non-electrolyte concentrations may enhance the importance of synovial fluid in examination of various modes of death as well as estimation of time passed after death (Arikeri et al., 2013).

\section{AIM OF THE WORK}

This work aimed to study the usefulness of synovial fluid biochemical investigations in determination of post-mortem interval.

\section{SUBJECTS \& METHODS}

\section{1- Subjects}

The study was done in medicolegal authority-Minia department in collaboration with forensic medicine and biochemistry departments of faculty of medicine, Minia University from June 2012 to July 2013. Because of higher rate of head injuries or firearm injuries victims that were admitted to medico-legal authority, all corpses were selected from these two types of death. The details regarding the 
age, sex, date, time of death, and the history were elicited from admission sheet of the victims.

Exclusion criteria of subjects included:

(1) Known cases of knee injury.

(2) Infection of knee.

(3) Synovial fluid found to be discolored and hemorrhagic.

(4) Corpse kept in cold storage.

(5) Unknown cases of time of death.

(6) Metabolic disorders.

After excluded cadavers, twenty-six cadavers ( 8 female and 18 male, ages 25-70 years old) who dead from head injuries or firearm injuries, were included in this study.

The synovial fluid samples were taken from:

10 cadavers at PMI 6-12h and PMI 13-18h

$>$ 2cadavers at PMI 13-18h

14 cadavers at PMI 13-18h and PMI19-24h

\section{2- Methods}

The synovial fluid was aspirated by puncture the lateral side of suprapatellar pouch or just under the patella
(Madea et al., 2001). Then measurement of:

a- urea: by brithlot method (Tietz, 1995).

b -Creatinine: by Jaffe method (Toora\&Rajagopal, 2002).

C- Na, K, and Cl: by ion select electrode (Tietz, 1994).

d- Calcium: by photometric test (Gurder and Zawta, 2001).

e- Glucose: by enzymatic colorimetric method (Keppy et al., 2009)

Statistical analysis were done using software SPSS version 13.

\section{Results:}

(I) -Anova test of biochemical values regarding PMI (Table 1):

Urea level increased at PMI 13-18h then decreased and this change was insignificant, but creatinine showed significant decrease with time (fig. 1). Regarding $\mathrm{Na}$, its level increased at PMI 13-18h then decreased insignificantly, but $\mathrm{Cl}$ level had significant decrease with time (fig. 2). There was significant change of $\mathrm{K}$ level (fig. 3). Significant increase in Ca (fig. 4), and glucose (fig. 5) were shown with time. 
Table (1): Anova test for biochemical parameters at different PMI:

\begin{tabular}{|c|c|c|c|c|}
\hline & $\begin{array}{c}6-12 \mathrm{~h}(\mathrm{I}) \\
\mathrm{N}=10\end{array}$ & $\begin{array}{c}13-18 h(\text { II }) \\
N=26\end{array}$ & $\begin{array}{c}19-24 h \text { (III) } \\
\mathrm{N}=14\end{array}$ & $P$ value \\
\hline $\begin{array}{c}\text { Urea: mg/dl } \\
\text { Range } \\
M \pm \text { SD }\end{array}$ & $\begin{array}{c}(9-40) \\
23.2 \pm 11.61\end{array}$ & $\begin{array}{c}(14-43) \\
30.8 \pm 9.91\end{array}$ & $\begin{array}{c}(12-44) \\
24.5 \pm 13.88\end{array}$ & 0.135 \\
\hline $\begin{array}{c}\text { Cr: mg/dl } \\
\text { Range } \\
M \pm \text { SD }\end{array}$ & $\begin{array}{c}(0.6-3.8) \\
2.02 \pm 1.35\end{array}$ & $\begin{array}{c}(0.4-2.2) \\
1.02 \pm 0.56\end{array}$ & $\begin{array}{c}(0.3-1.1) \\
0.67 \pm 0.37\end{array}$ & $0.015 *$ \\
\hline $\begin{array}{c}\text { Na: } \mathrm{mg} / \mathrm{dl} \\
\text { Range } \\
\mathrm{M} \pm \mathrm{SD}\end{array}$ & $\begin{array}{c}(115-151) \\
138.2 \pm 11.36\end{array}$ & $\begin{array}{c}(120-160) \\
145.07 \pm 12.92\end{array}$ & $\begin{array}{c}(135-147) \\
140.21 \pm 10.22\end{array}$ & 0.146 \\
\hline $\begin{array}{c}\text { K: mg/dl } \\
\text { Range } \\
M \pm S D\end{array}$ & $\begin{array}{c}(5-6.1) \\
5.81 \pm 0.376\end{array}$ & $\begin{array}{c}(3.1-4.7) \\
3.65 \pm 0.56\end{array}$ & $\begin{array}{c}(4-5.5) \\
4.95 \pm 0.67\end{array}$ & $<0.001 *$ \\
\hline $\begin{array}{c}\text { Cl: } \mathrm{mg} / \mathrm{dl} \\
\text { Range } \\
\mathrm{M} \pm \mathrm{SD}\end{array}$ & $\begin{array}{c}(105-135) \\
114.5 \pm 9.48\end{array}$ & $\begin{array}{c}(90-110) \\
101.96 \pm 5.98\end{array}$ & $\begin{array}{c}(95-109) \\
100.35 \pm 6.81\end{array}$ & $<0.001 *$ \\
\hline $\begin{array}{c}\text { Ca: mg/dl } \\
\text { Range } \\
\mathrm{M} \pm \mathbf{S D}\end{array}$ & $\begin{array}{c}(4-7.4) \\
5.64 \pm 1.26\end{array}$ & $\begin{array}{c}(5-8.7) \\
7.17 \pm 1.22\end{array}$ & $\begin{array}{c}(6.9-7.9) \\
7.20 \pm 0.45\end{array}$ & $0.004 *$ \\
\hline $\begin{array}{c}\text { Glucose:mg/dl } \\
\text { Range } \\
\mathrm{M} \pm \mathrm{SD}\end{array}$ & $\begin{array}{c}(24-60) \\
37.1 \pm 12.84\end{array}$ & $\begin{array}{c}(12-140) \\
58.61 \pm 47.13\end{array}$ & $\begin{array}{c}(80-100) \\
91.42 \pm 8.09\end{array}$ & $0.001 *$ \\
\hline
\end{tabular}

$\mathrm{M}=$ mean value $\mathrm{SD}=$ standered deviation

$P$ value $<0.05=$ significant

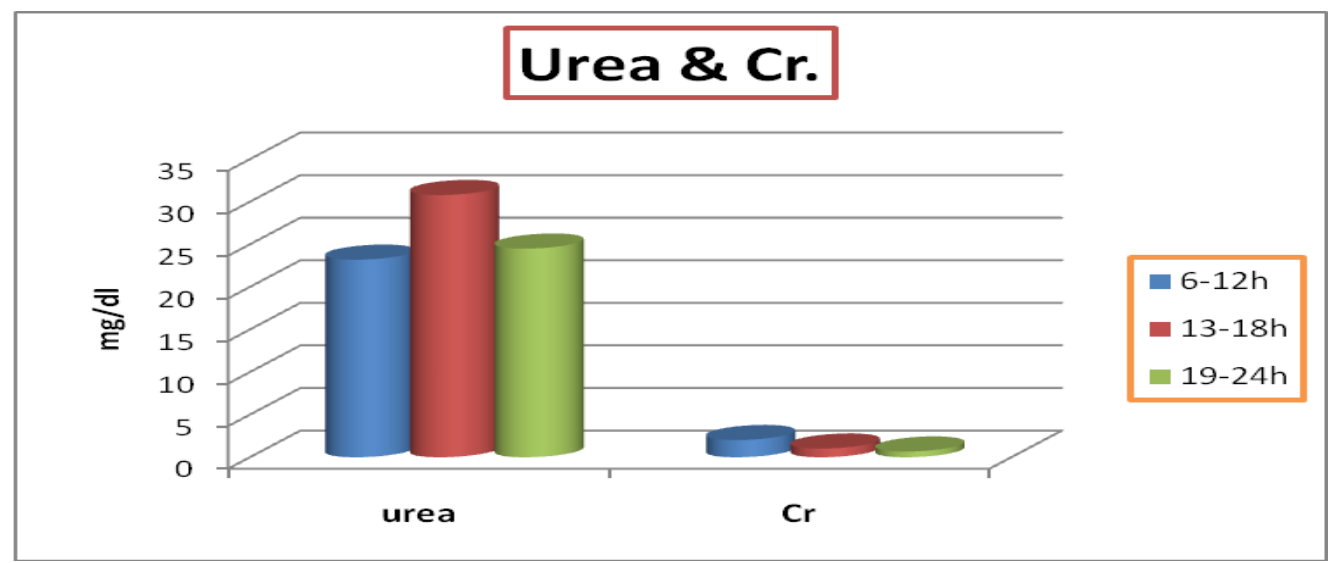

Figure (1): Urea \& creatinine at different PMI 


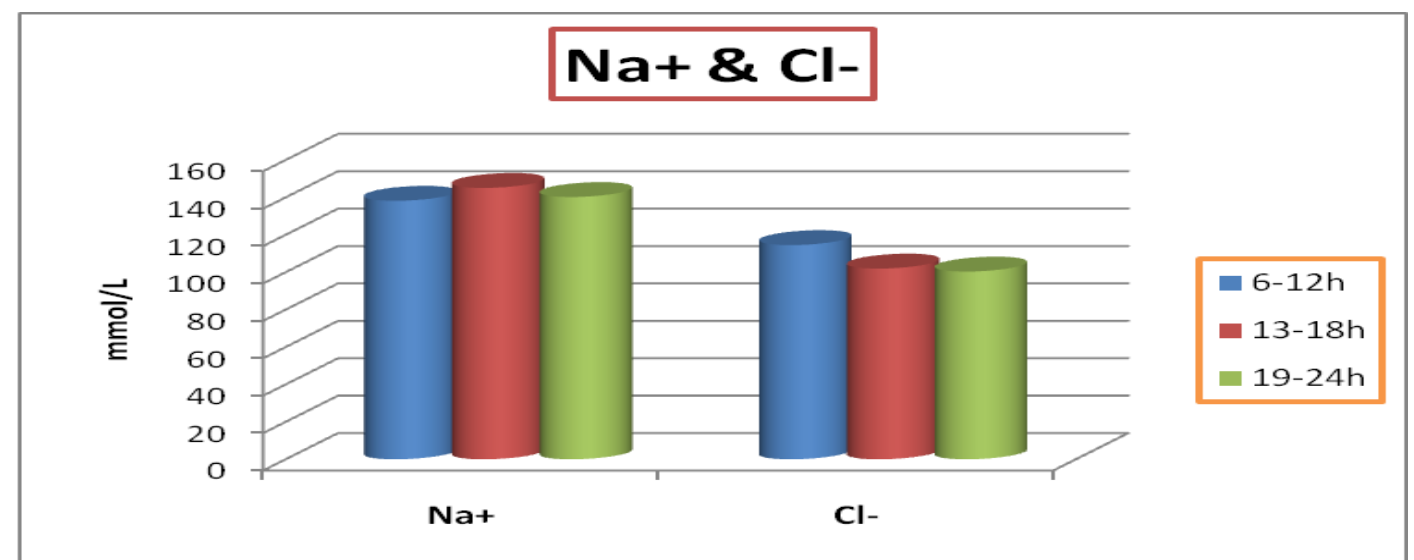

Figure (2): $\mathrm{Na \& Cl}$ at different PMI

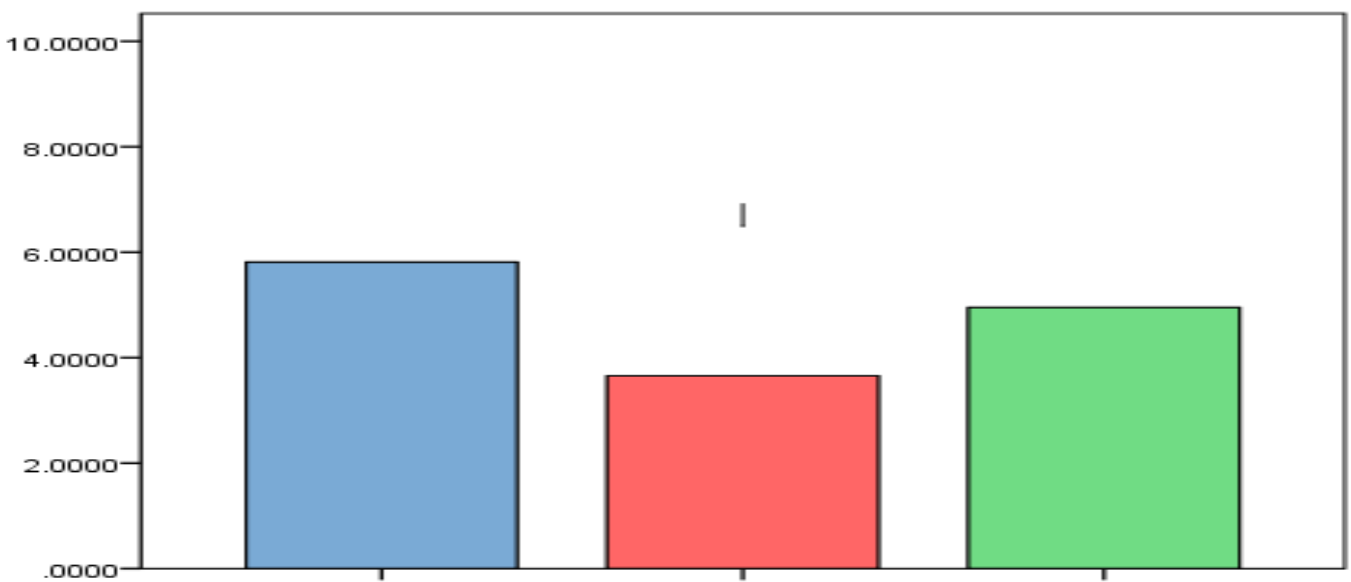

Figure (3): Potassium at different PMI

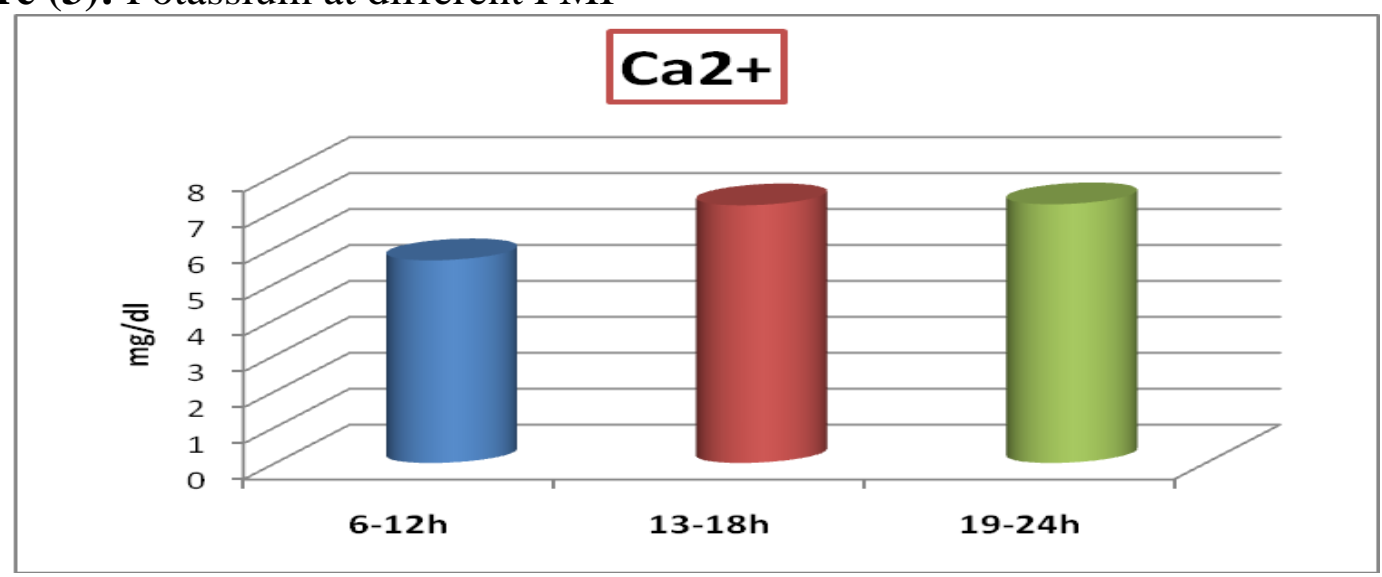

Figure (4): Calcium at different PMI 


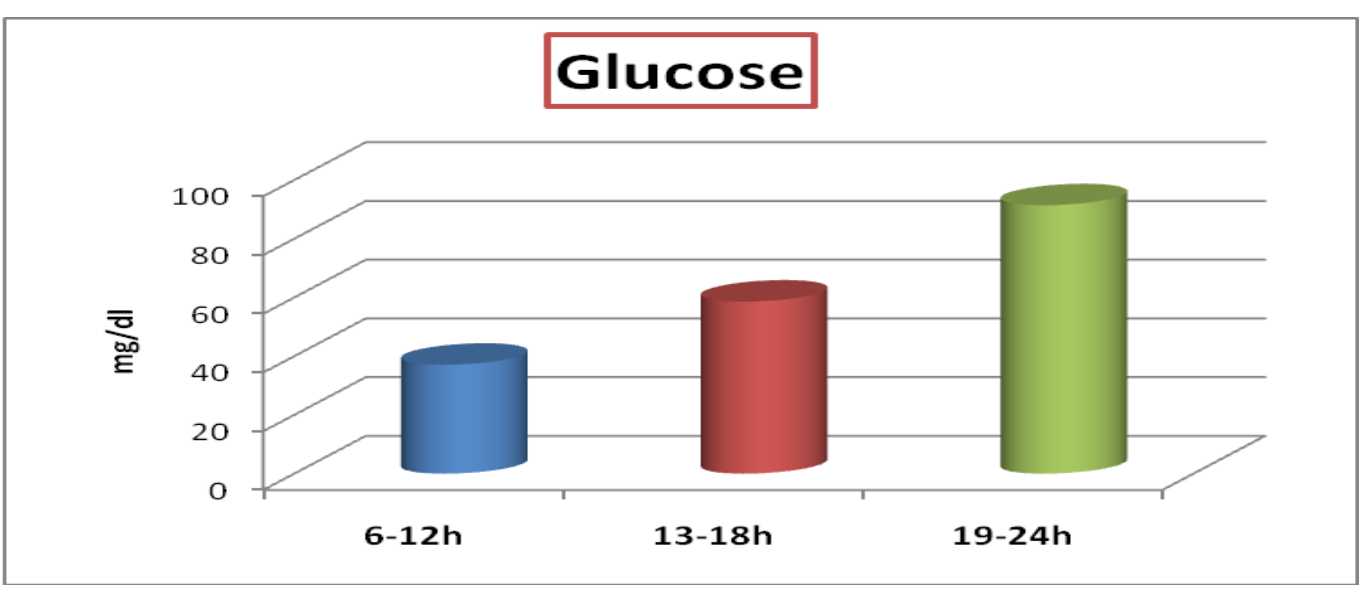

Figure (5): Glucose at different PMI

II- Correlation (table 2), simple regression (table 3-6), and multiple regression (table 7) analysis between cadaveric synovial fluidbiochemical values and PMI:

There were no correlation of urea (fig. 9) with PMI. Significant weak negative correlation was shown in creatinine (fig. 7), and chloride (fig. 10) with time. Positive correlation was noticed in glucose moderately (fig. 12), and calcium weakly (fig. 11). (fig. 6), sodium (fig.8), and potassium

Table (2): correlation between constituents values of synovial fluid \&PMI:

\begin{tabular}{|c|c|c|}
\hline \multirow{2}{*}{ Urea } & r & PMI \\
\cline { 2 - 3 } & $\mathbf{P}$ & -0.022 \\
\hline \multirow{2}{*}{ Cr. } & $\mathbf{r}$ & 0.879 \\
\cline { 2 - 3 } & $\mathbf{P}$ & -0.383 \\
\hline \multirow{2}{*}{ Na } & $\mathbf{r}$ & $0.006^{*}$ \\
\cline { 2 - 3 } & $\mathbf{P}$ & -0.192 \\
\hline \multirow{2}{*}{$\mathbf{K}$} & $\mathbf{r}$ & 0.183 \\
\cline { 2 - 3 } & $\mathbf{P}$ & 0.004 \\
\hline \multirow{2}{*}{ Cl } & $\mathbf{r}$ & 0.980 \\
\cline { 2 - 3 } & $\mathbf{P}$ & -0.366 \\
\hline \multirow{2}{*}{ Ca } & $\mathbf{r}$ & $0.009^{*}$ \\
\cline { 2 - 3 } & $\mathbf{P}$ & 0.378 \\
\hline \multirow{2}{*}{ Glucose } & $\mathbf{r}$ & $0.007^{*}$ \\
\cline { 2 - 3 } & $\mathbf{P}$ & 0.673 \\
\hline \multirow{2}{*}{ r= correlation } & $\mathbf{P ~ v a l u e}<\mathbf{0 . 0 5}=$ significant \\
\hline
\end{tabular}




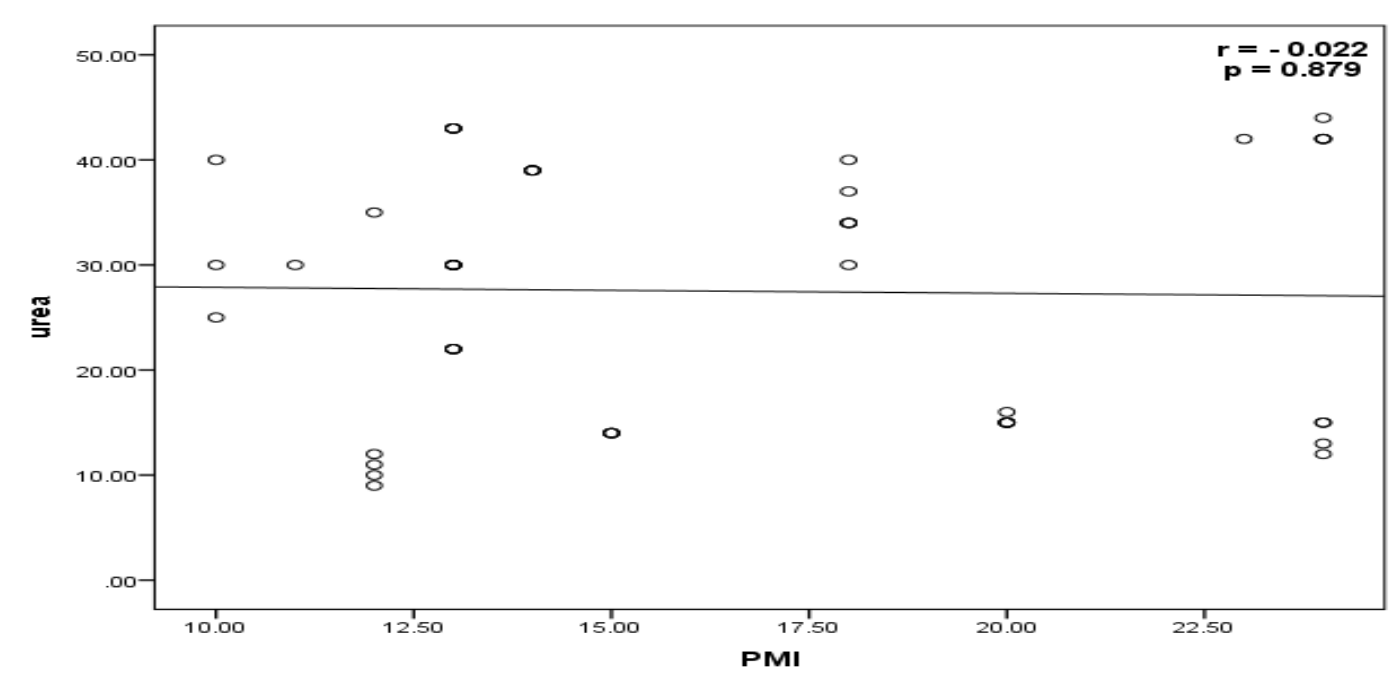

Figure (6): correlation of urea with PMI

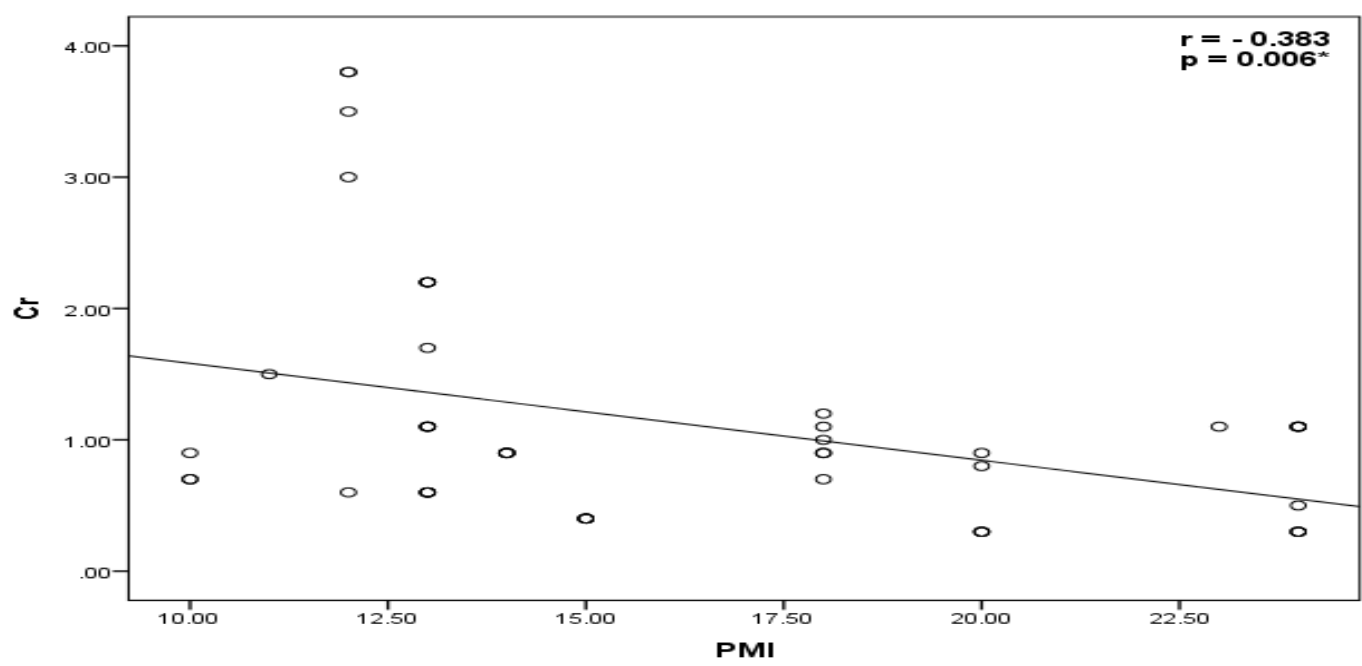

Figure (7): correlation of creatinine with PMI

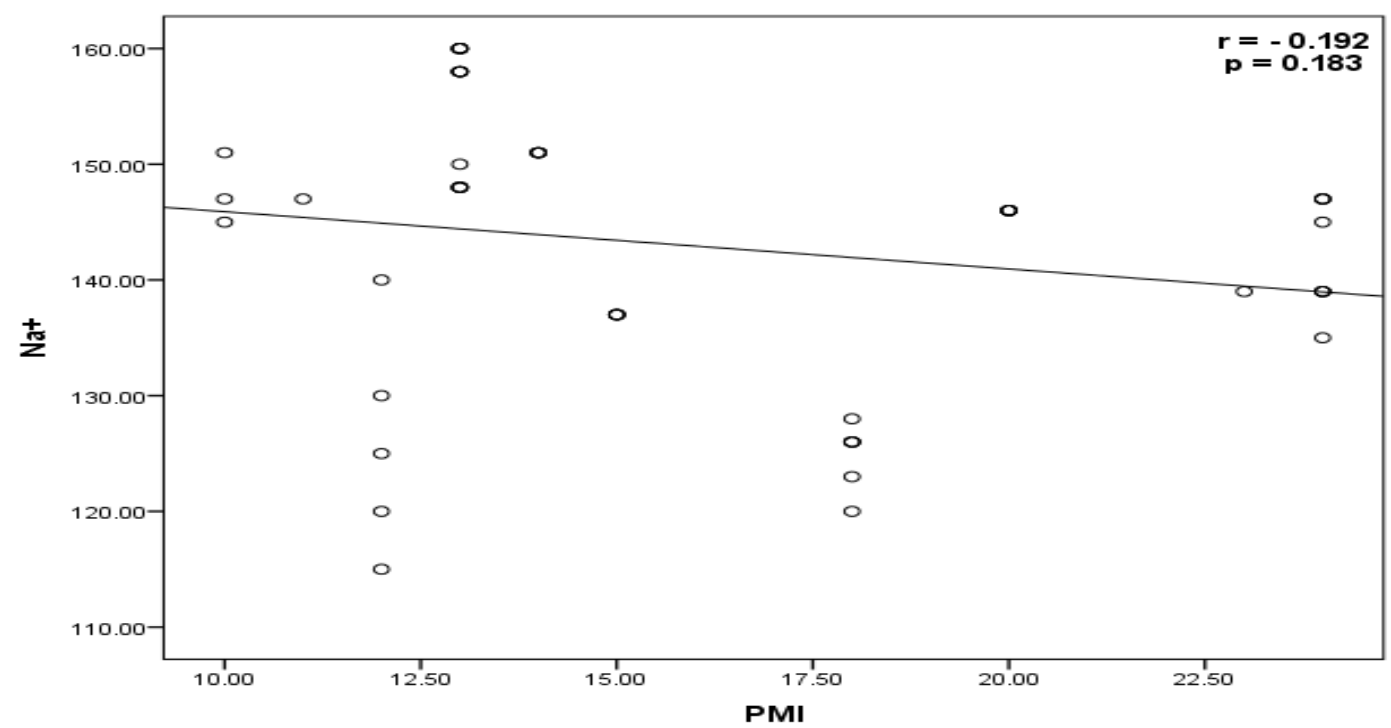

Figure (8): correlation of Na with PMI 


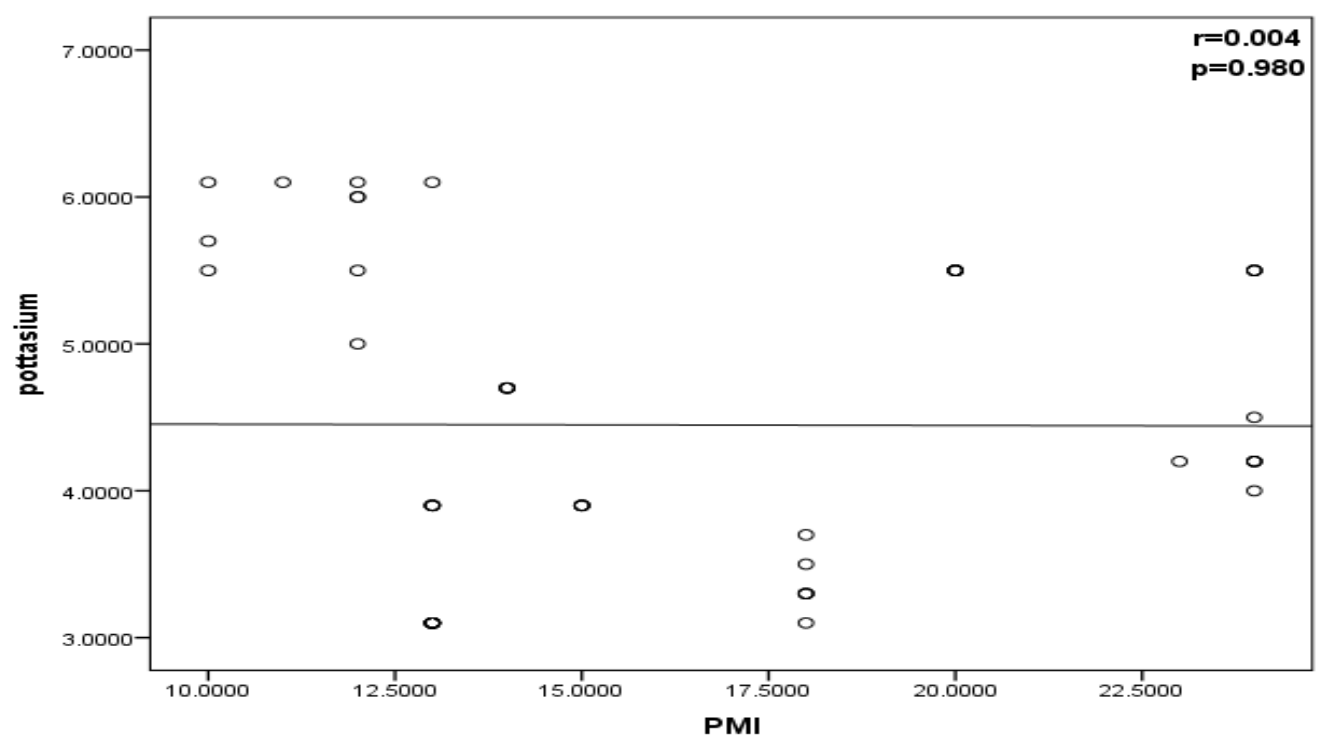

Figure (9): correlation of K with PMI

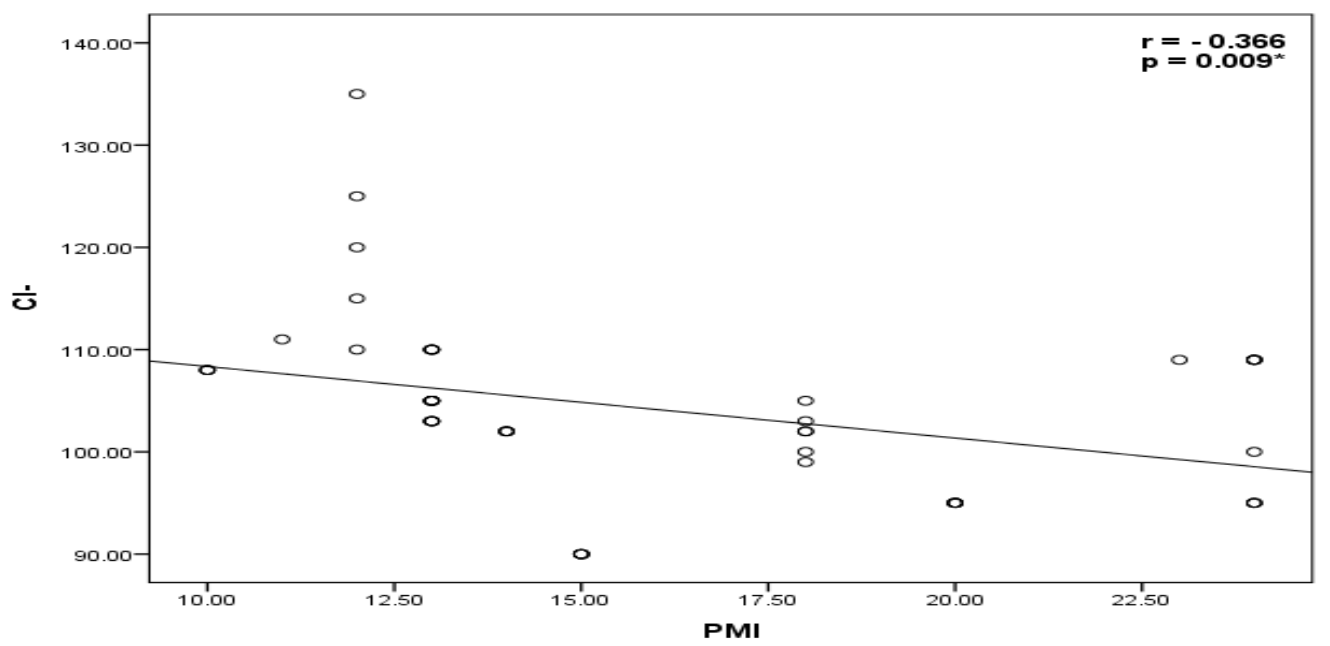

Figure (10): correlation of $\mathrm{Cl}$ with $\mathrm{PMI}$

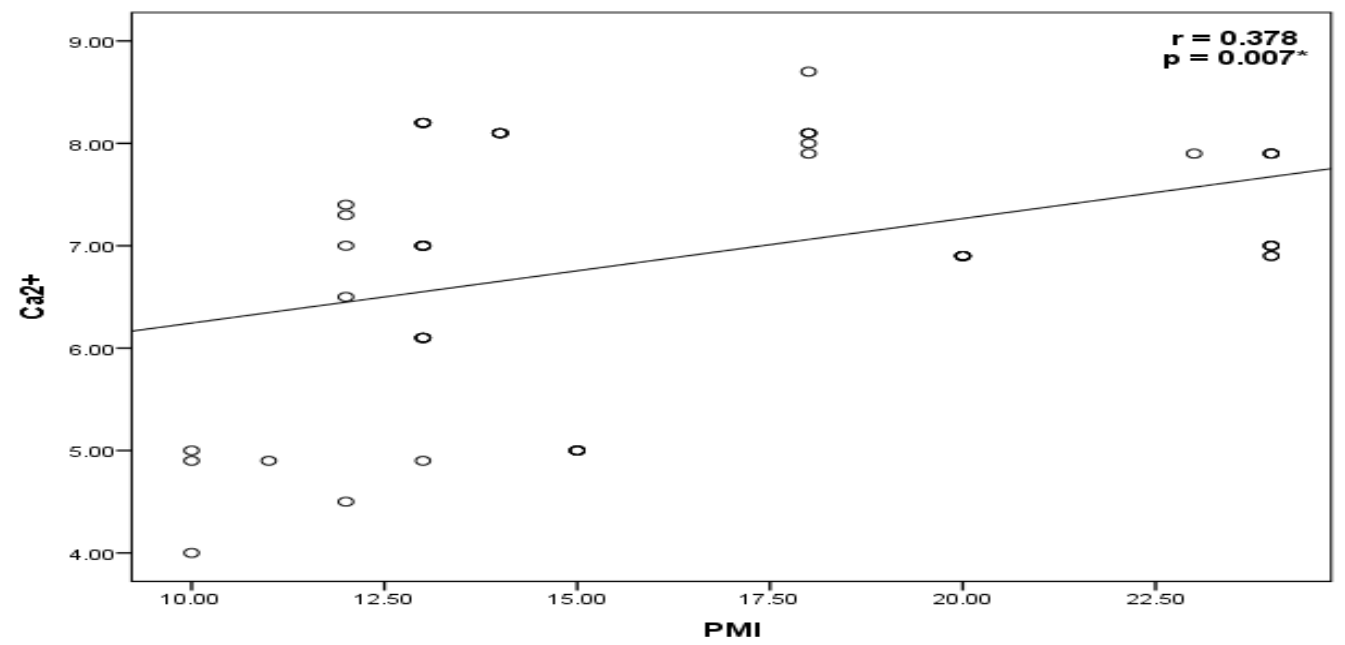

Figure (11): correlation of Ca with PMI 


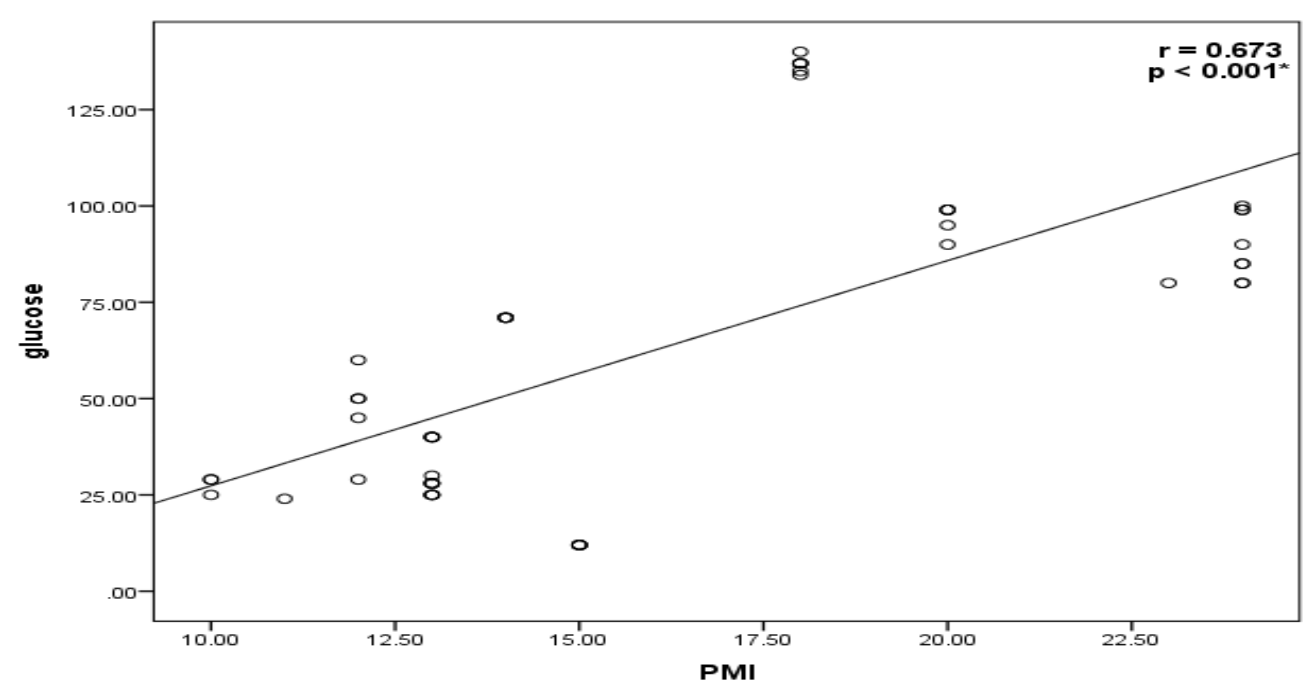

Figure (12): correlation of glucose with PMI

Simple regression analysis by obtain the least square regression equation used to calculate post-mortem interval by:

PMI=B0 (constant) + B1 (parameter)

Cr: $\quad$ PMI $=(18.421)+(-1.990)$ Cr level (table 3).

CL: $\quad$ PMI $=(36.091)+(-0.191)$ Cl level (table4).

Ca: $\quad$ PMI $=(6.530)+(1.403)$ Ca level (table5).

Glucose: $\quad$ PMI $=(11.255)+(0.078)$ glucose level (table 6).

The best parameter was glucose because $R 2=0.453$

Table (3): simple regression analysis of creatinine

\begin{tabular}{|c|c|c|}
\hline & $\mathbf{R}$ & $\mathbf{R}^{\mathbf{2}}$ \\
\hline $\mathbf{C r}$ & 0.383 & 0.147 \\
\hline $\mathbf{B 0}$ (constant) & coefficients & P value \\
\hline B1 & 18.421 & $<0.001^{*}$ \\
\hline
\end{tabular}

Table (4): Showing simple regression analysis of $\mathrm{Cl}$

\begin{tabular}{|c|c|c|}
\hline & $\mathbf{R}$ & $\mathbf{R}^{\mathbf{2}}$ \\
\hline Cl & 0.366 & 0.134 \\
\hline B0(constant) & coefficients & P value \\
\hline B $_{1}$ & 36.091 & $<0.001 *$ \\
\hline
\end{tabular}

Table (5): Showing simple regression analysis of Ca:

\begin{tabular}{|l|c|c|}
\hline & $\mathbf{R}$ & $\mathbf{R}^{\mathbf{2}}$ \\
\hline $\mathrm{Ca}$ & 0.378 & 0.143 \\
\hline & Coefficients & P value \\
\hline $\mathrm{B}_{0}$ (constant) & 6.530 & 0.065 \\
\hline $\mathrm{B}_{1}$ & 1.403 & $0.007^{*}$ \\
\hline
\end{tabular}


Table (6): Showing simple regression analysis of glucose:

\begin{tabular}{|c|c|c|}
\hline & $\mathrm{R}$ & $\mathrm{R}^{2}$ \\
\hline Glucose & 0.673 & 0.453 \\
\hline & Coefficients & $\mathrm{P}$ value \\
\hline $\mathrm{B}_{0}$ (constant) & 11.255 & $<0.001^{*}$ \\
\hline $\mathrm{B}_{1}$ & 0.078 & $<0.001^{*}$ \\
\hline
\end{tabular}

Table (7): Showing multiple regression analysis of glucose and chloride

\begin{tabular}{|c|c|c|}
\hline & $\mathrm{R}$ & $\mathrm{R}^{2}$ \\
\hline Glucose $\& \mathrm{Cl}$ & 0.724 & 0.525 \\
\hline & Coefficients & $\mathrm{P}$ value \\
\hline $\mathrm{B}_{0}$ (constant) & 26.26 & $<0.001^{*}$ \\
\hline $\mathrm{B}_{1}$ & 0.073 & $<0.001^{*}$ \\
glucose & -0.141 & $<0.011^{*}$ \\
$\mathrm{Cl}$
\end{tabular}

Multiple stepwise regression analysis by obtain the least square regression equation used to calculate post-mortem interval by:

PMI = B0 (constant) + B1glucose (its level) $+\mathbf{B 1 C l}$ (its level)

PMI $=26.26+0.073$ (glucose level) $+(-0.141)$ (chloride level)

\section{DISCUSSION}

It is very important to determine time of death quickly, with accuracy and precision (Nandy,2010).Many researches about postmortem changes studied several biological fluids, and described that the favorite of them were those withstood putrefaction for long time, such as vitreous humor, cerebrospinal fluid, and pericardial fluid (Biswas,2010).

As synovial fluid is more protected and less prone to burns or atmospheric variations, it was thought that the postmortem chemistry of it might be helpful in estimating post-mortem interval with more accuracy (Sheikh, 2007).

Synovial fluids were aspirated from twenty-six cadavers: at PMI 6-12h (group I), 13-18h (group II), and 1924h (group III).Synovial fluid was analyzed for measurement of urea, creatinine, $\mathrm{Na}, \mathrm{K}, \mathrm{Cl}, \mathrm{Ca}$, and glucose levels.

This study showed insignificant change of urea and sodium at different postmortem intervals, and that results are in agreement with Tumram et al., 2011. Synovial fluid Sodium concentration measured by sodium flam photometer, had irregular change and correlation with increasing post mortem interval (Sheikh, 2008).

Creatinine levels had significant decrease and negative correlation with increasing PMI in this research. These results are in contrary with Nishida et al., 2015, who found that the blood creatinine level was high. The suggestion of that controversary may be due to the difference in cause of death which were intoxication and fire in their research but were head injuries and firearm injuries in our research.

Arikeri et al., 2013, concluded that potassium level in synovial fluid had significant change in relation to post mortem period, as the present research detected. The rise of potassium levels were more synovial fluid than vitreous fluid (Madea et al., 2001).

The current study showed significant decrease and negative correlation on comparing the chloride 
levels with increasing postmortem interval, and these findings are in accordance with Tumram et al., 2011, who used ion selective meter for analysis of chloride in synovial and found significant decrease in its level with time passed since death.

Calcium level showed significant increased and positive correlation with increasing PMI. Maeda et al., 2011, found that calcium concentration was immediately increased after death then stable, followed by a final descent of calcium as a result of decomposition. But Connolly et al., 2016, found that the serum calcium level after death remains shortly stable then rises slowly until decomposition occur.

In this study, there is significant increased and strong positive correlation on glucose levels with time lapsed. Madea, 2005, suggested that the increased the blood glucose level due to postmortem breakdown of carbohydrates in the gastro-intestinal tract.

Contrary to Trivedi \& Narayana, 2015 who demonstrates that the blood glucose level fall in postmortem samples, and that fall is because of the continuation of metabolic reactions and glycolysis after somatic death of an individual.

According to the results of the current study, It can be concluded that measurement the synovial fluid levels of glucose+ chloride $(\mathrm{R} 2=0.525)$ or glucose alone $(\mathrm{R} 2=0.453)$ may be helpful in determination of PMI.

level

$$
\text { PMI }=(\text { B0 })+(\text { B1 }) \text { parameter }
$$

$=(26.26)+(0.073)$ glucose level + $(-0.141)$ chloride level

$$
\text { Or }=(11.255)+(0.078) \text { glucose }
$$
level
Finally it is recommended to do more researches about synovial fluid analysis for diagnosis of the cause of death, and to know the effect of pathological process on modification of synovial fluid parameters in determination of postmortem interval.

\section{REFERENCES}

Arikeri S.M., Laveesh M.R., Priyadarshini A.V., et al. (2013): Determination of time since death by estimating sodium and potassium levels in synovial fluid. Int J Pharm Biomed Res, 4(4):194196.

Biswas G. (2010): Review of Forensic Medicine \& Toxicology, 1st edition, P: 109, Jaypee Publication.

Connolly A.J., Finkbiener W.E.,Ursell P.C. and Davis R.L. (2016): (supplemental laboratory studies) in: Autopsy pathology a manual and atlas, chapter 10, pp 136, third edition, Philadelphia.

Gurder W.G. and Zawta B. (2001): The quality of Diagnostic Samples,1st ed., p:20-1,50-1, Darmstad; GIT Verlag.

Keppy N.K., Bain G. and Allen M.W. (2009): Enzymatic Colorimetric Methods for the Analysis of Human Serum by UV-Visible Spectroscopy. Thermo Fisher Scientific, Madison, WI, USA.

Madea B. (2005): Is there recent progress in the estimation of postmortem interval by means of thanato-chemistry?

Forensic science international, 151: 139-149.

Madea B., Kreuser C. and Banaschak S. (2001): Postmortem biochemical examination of synovial fluid -a preliminary study. Forensic science international, 118(200):29-35. 
Maeda H., Ishikawa T. and Michiue T. (2011): forensic biochemistry for functional investigation of death: concept and practical application. Legal Medicine (Tokyo), 13: 55-67.

Nandy A. (2010): Principles of Forensic Medicine including Toxicology 3rd ed., P: 280.

Nishida A., Funaki H., Kobayashi M., Tanaka Y., Akasaka Y., Kubo T. and Ikegaya H. (2015): Blood creatinine level in postmortem cases. Sci. Justice, 55(3):195-9.

Palmiere C., Lesta M., Sabatasso S., Mangin P., Augsburger M. and Sporkert F. (2012): Usefulness of postmortem biochemistry in forensic pathology: Illustrative case reports. Legal Medicine, 14 (1): 27-35.

Sheikh N.A. (2007): Estimation of post-mortem interval according to time course of Potassium ion activity in cadaveric synovial fluid. Indian Journal of Forensic Medicine \& Toxicology, 1: $45-49$.

Sheikh N.A. (2008): Study of Sodium $\&$ Glucose levels in Cadaveric Synovial Fluid to Estimate PostMortem Interval-. Indian Journal of Forensic Medicine and Pathology, 1: 3 - 4.

Singh D., Prashad R., Sharma S.K., et al. (2006): Estimation of postmortem interval from human pericardial fluid electrolytes concentrations in Chandigarh zone of India: Log transformed linear regression model. Legal Medicine, 8: 279-287.

Tietz N. W. (1994): Clinical Chemistry. Philadelphia, Pa: $2^{\text {nd }}$ ed., WB Saunders Co: 1356, 1364, 1365.

Tietz NW. (1995): Clinical guide to laboratory tests, 3rd ed., P: 46-50, Philadelphis WB saunders.

Toora B.D. and Rajagopal G. (2002): Measurement of creatinine by Jaffe's reaction--determination of concentration of sodium hydroxide required for maximum color development in standard, urine and protein free filtrate of serum. Indian J Exp Biol, 40 (3): 352-4.

Trivedi D. and Narayana K.S. (2015): Postmortem blood glucose level: how useful to envisage the time since death. International Journal of Clinical Biochemistry and Research 2(1): 61-64.

Tumram N.K., Bardle R.V. and Dongre A.P. (2011): Postmortem analysis of synovial fluid and vitreous humor for determination of death interval: A comparative study. Forensic science international, 204:186-190. 


\section{فوائد الفحص البيوكيمياى للسائل الزليلي بعد الموت}

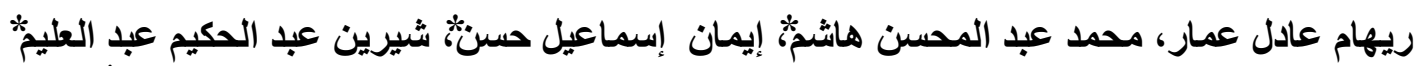

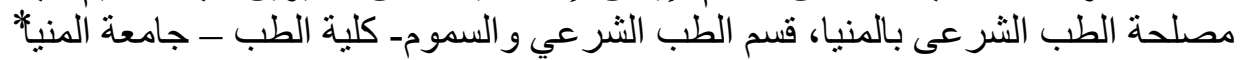

$$
\text { الملخص العربى }
$$

تحديد وقت الوفاة من التغييرات التى تحدث بعد الوفاة مثل البرودة و التيبس الرمى يكون أقل دقة مع مرور

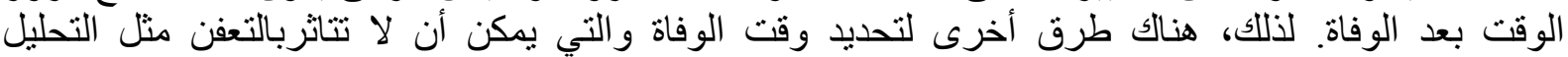

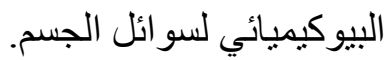

لهذا السبب، تم إجراء هذه الدراسة لتحديد وقت الوفاة من خلال قياس معدلات اليوريا والكرياتينين

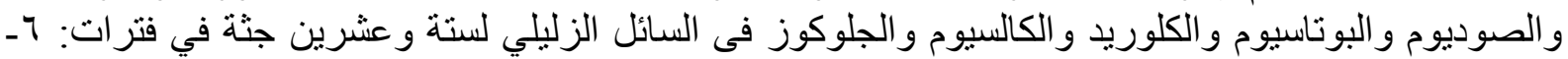

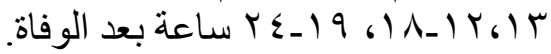

وقد كثنفت نتائج التحليل البيوكيميائي أن معدلات قيم اليوريا والصوديوم لم يكن لها تغير ذو دو دلالة احصائية

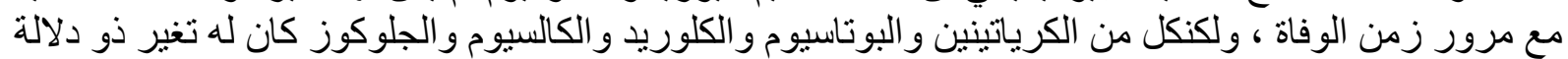

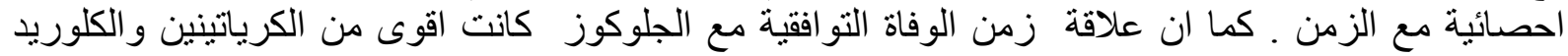

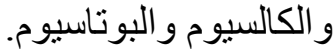

نستتنج مما سبق أن قياس معدلا الجلوكوز+الكلوريد معا يليه معدل الجلوكوز وحده في السائل الزليلي قد

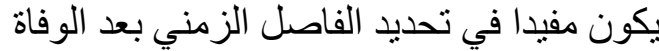

